\title{
CORRELATED RESPONSE IN CARCASS TRAITS WHEN USING SELECTION INDEXES INVOLVING MARKETING BODY WEIGHT AND DAILY GAIN IN NEW ZEALAND WHITE RABBITS
}

\section{G.F. Gouda}

Animal Production Department, Faculty of Agriculture, Ain Shams University, Shoubra El-Kheima, Cairo, Egypt

\section{SUMMARY}

Estimates of genetic and phenotypic parameters for live body and carcass traits on 121 New Zealand White rabbits, progeny of unrelated 13 bucks and 56 does were calculated and used to construct ten selection indexes. Traits in the aggregate genotype were marketing body weight (at 90 days) and daily gain from weaning to marketing. The index traits were body weight (at weaning and at marketing and daily gain between them) and body linear measurements (abdominal girth, body length and ear length). It is more efficient to use body weight traits indexes than body linear measurements indexes ( $r_{T I}=0.87$ to 0.92 vs. 0.20 to 0.85 , respectively) in predicting the true breeding value. Use of the index $I_{2}=-0.82$ weaning weight +36.9 daily gain + 0.92 marketing weight (having $r_{T I}=0.92$ ) would be recommended to optimize selection for the given aggregate genotype and should result in rabbits characterized with heavier marketing weight (+153 g), faster daily gain $(+2.3 \mathrm{~g})$, better muscle to bone ratio (+0.2 unit) and enhancement of boneless percentage (+0.4 unit). However, genetic gain in marketing body weight and daily gain would be coupled with decrease in weaning weight (-19 g) and fatless side percentage (-0.4 unit) along with its percentage components of muscle (-0.4 unit) and bone (-0.4 unit). In the absence of growth records, the index $I_{10}=+85.0$ abdominal girth -72.1 ear length 17.5 body length would be recommended.

Keywords: New Zealand white rabbits, selection indexes, live body and Carcass traits

\section{INTRODUCTION}

Weaning and marketing body weights together with daily gain are among the most important growth traits in meat rabbit production for their close relationship to efficiency of production. Selection on these traits can modify the whole growth curve, changing the age at which commercial slaughter weight should be appropriately fixed. However, due to their short generation interval and lower degree of maturity at slaughter (Blasco et al., 1996, Estany et al., 1992), selection on daily gain might lead to undesirable consequences in carcass composition.

The aim of present work was to investigate the impact of improving marketing body weight and daily gain in New Zealand White (NZW) rabbits on fundamental carcass traits, via selection indexes.

Issued by The Egyptian Society of Animal Production 


\section{MATERIALS AND METHODS}

\section{Source of Data}

A random sample of weanling NZW rabbits (85 males and 36 females), progeny of 13 bucks and 56 mature does were used in the present study. The rabbits were born (March-April, 1996) and reared in the private Sanafer Rabbit farm, Kalyobia, Egypt then slaughtered, dressed out and their carcasses jointed and dissected in the Meat laboratory of Animal Production Department, Faculty of Agriculture, Ain Shams University.

\section{Management of Animals}

Following their birth, rabbits were kept with their dams in breeding batteries till weaning at 28 days of age, by which time they were ear tagged, weighed and moved to fattening batteries. They were fed ad libitum a commercial pelleted diet containing $18.8 \%$ crude protein, $11.0 \%$ crude fiber and $2.4 \%$ crude fat and providing $2800 \mathrm{Kcal}$ digestible energy $/ \mathrm{kg}$ diet until slaughtering at 90 days of age.

\section{Traits considered}

Live body traits were measured at weaning and at marketing (90 days). Before slaughter, abdominal girth at its maximum perimeter, body length and ear length were measured. Rabbits were slaughtered, dressed out and their hot carcasses weighed and split. The right sides were packed in polyethylene bags and deep frozen before stored at $-18^{\circ} \mathrm{C}$. After thawing in their closed bags, the sides were jointed (Blasco et al., 1992) into four cuts viz, fore leg, thoracic cage, loin and hind leg cuts. The fat (subcutaneous plus intermuscular), muscles, and bones of each cut were dissected and weighed and summed up over the side to give the dissected side fat, muscles and bones. The sum of those totals gives the dissected side weight. Carcass traits were side muscles, bones and fat. Fatless and boneless side, and muscle to bone ratio were also calculated.

\section{Statistical analysis}

The genetic and phenotypic parameters for the traits considered were estimated by the Least Square and Maximum Likelihood program (Harvey, 1990) according to the following mixed model:

where:

$$
\mathbf{Y}_{\mathrm{ijkl}}=\boldsymbol{\mu}+\mathbf{S}_{\mathrm{i}}+\mathbf{D}_{\mathrm{ij}}+\mathbf{G}_{\mathrm{k}}+\mathbf{e}_{\mathrm{ijkl}}
$$

$\mathrm{Y}_{\mathrm{ijkl}}=$ The observation on the $1^{\text {th }}$ rabbit of the $\mathrm{k}^{\text {th }}$ sex from the $\mathrm{j}^{\text {th }}$ dam and $\mathrm{i}^{\text {th }}$ sire;

$\mu=$ the overall mean;

$\mathrm{S}_{\mathrm{i}}=$ the random effect of $\mathrm{i}^{\text {th }}$ sire $(i=1,2, \ldots \ldots \ldots . . ., 13)$;

Dij $=$ the random effect of $\mathrm{j}^{\text {th }}$ dam $(\mathrm{j}=1,2, \ldots \ldots . .56$, number of dames mated to each

sire are not equal) nested within the $i^{\text {th }}$ sire;

$\mathrm{Gk}=$ the fixed effect of the $\mathrm{k}^{\text {th }} \operatorname{sex}(\mathrm{k}=1,2)$;

eijkl $=$ the random error assumed to be N.I.D $\left(0, \sigma^{2} \mathrm{e}\right)$ 
Whereas, the estimates of genetic and phenotypic parameters from sire component alone or dam component alone yielded aberrant estimates, thus estimates reported here were from full sib component $\left(h^{2}=2\left(\sigma^{2} s+\sigma^{2} d\right) /\left(\sigma^{2} s+\sigma^{2} d+\sigma^{2} e\right)\right)$.

\section{Definition of true breeding value}

The true breeding value $(\mathrm{T})$ was defined as:

$$
\mathrm{T}=\mathrm{g}_{1} \mathrm{v}_{1}+\mathrm{g}_{2} \mathrm{v}_{2}
$$

where:

$\mathrm{g}_{1}=$ additive genetic value for marketing body weight;

$\mathrm{g}_{2}=$ additive genetic value for daily gain;

$\mathrm{v}_{1}$ and $\mathrm{v}_{2}=$ relative economic values for marketing body weight and daily gain, respectively.

\section{Relative economic values}

While, the rabbit weight is the only limiting factor, until now, for determining the price to the rabbit consumer, marketing body weight was assumed to be twice as important as daily gain in present study. That is mean that, every one gram increase in marketing weight will bring twice the profit as one gram increase in daily gain.

\section{Selection Strategies}

Weaning weight, daily gain, marketing body weight, abdominal circumference, body length and ear length were used in different combinations to construct ten selection indexes (Cunningham et al., 1970). The combinations were based on the following strategies:

- Strategy 1: selection on body weight traits and body linear measurements;

- Strategy 2: selection on body weight traits alone; and

- Strategy 3: selection on body linear measurements alone.

\section{RESULTS AND DISCUSSION}

\section{Heritabilities}

Estimates of $\mathrm{h}^{2}$ for the traits considered in the present study are given in Table 1. Full sibs $\mathrm{h}^{2}$ estimates reported for NZW in the literature and those obtained in the present experiment indicate high values for weaning weight $(0.63$, Shemeis and Abdallah, 2000; 0.70, Table 1) and marketing weight (0.82, Shemeis and Abdallah, 2000; 0.79, Table 1) and low values for body length (0.14, Shemeis and Abdallah, 2000; 0.29, Table 1).

\section{Correlations}

Estimates of genetic and phenotypic correlations between the traits considered in this study are shown in Table 2.

\section{Genetic association between live body traits}

At fixed slaughter age, rabbits with faster daily gain would be heavier at marketing $\left(\mathrm{r}_{\mathrm{G}}=0.92\right.$, Table2; 0.98, Lukefahr et al., 1996; 0.96, Polestre et al., 1992; 0.72 ; Niedzwiadek, 1978) with negligible change in daily gain $\left(\mathrm{r}_{\mathrm{G}}=-0.03\right.$, Table 2 ; 
0.04, Niedzwiadek, 1978). Greater abdominal circumference was genetically associated with higher body length $\left(\mathrm{r}_{\mathrm{G}}=0.46\right)$ and lower ear length $\left(\mathrm{r}_{\mathrm{G}}=-0.77\right)$. Abdominal circumference was found to be a good genetic indicator for daily gain and marketing body weight $\left(\mathrm{r}_{\mathrm{G}}=0.89\right.$ and 0.90 , respectively).

Table 1. Unadjusted means $\overline{(X}, \pm$ standard errors) and heritability $\left(h^{2}\right)$ estimates ( \pm standard errors) for live body and carcass traits

\begin{tabular}{lcc}
\hline Trait & $\overline{\mathrm{X}} \pm \mathrm{SE}$ & $\mathrm{h}^{2} \pm \mathrm{SE}$ \\
\hline $\begin{array}{l}\text { i. Live body traits } \\
\text { a. Body weights }\end{array}$ & \\
$\quad$ Weaning weight (g) & $415 \pm 8.38$ & $0.70 \pm 0.21$ \\
$\quad$ Marketing body weight (g) & $1920 \pm 29.55$ & $0.75 \pm 0.22$ \\
$\quad$ Daily gain from weaning to marketing (g/day) & $23.9 \pm 0.46$ & $0.85 \pm 0.16$ \\
b. Body linear measurements, cm & & \\
Abdominal girth & $26.0 \pm 0.16$ & $0.71 \pm 0.21$ \\
Body length & $31.3 \pm 0.14$ & $0.29 \pm 0.22$ \\
Ear length & $11.6 \pm 0.06$ & $0.39 \pm 0.23$ \\
ii. Carcass traits & & \\
Fatless side (\%) & $96.3 \pm 0.12$ & $0.58 \pm 0.22$ \\
Boneless side (\%) & $88.6 \pm 0.12$ & $0.61 \pm 0.23$ \\
$\quad$ Side muscles (\%) & $84.9 \pm 0.10$ & $0.48 \pm 0.23$ \\
Side bones (\%) & $11.4 \pm 0.16$ & $0.60 \pm 0.22$ \\
Side fat (\%) & $3.7 \pm 0.15$ & $0.67 \pm 0.21$ \\
$\quad$ Side muscle: bone & $7.5 \pm 0.06$ & $0.57 \pm 0.23$ \\
\hline
\end{tabular}

\section{Genetic association between carcass traits}

Genetic improvement in fatless side percentage would greatly raise its content of muscles and moderately increase its content of bones $\left(\mathrm{r}_{\mathrm{G}}=0.90\right.$ and 0.36 , respectively) and decrease boneless side percentage $\left(\mathrm{r}_{\mathrm{G}}=-0.51\right)$ and its content of fat $\left(\mathrm{r}_{\mathrm{G}}=-0.57\right)$, reflecting genetic antagonism between bone and fat percentage $\left(\mathrm{r}_{\mathrm{G}}\right.$ $=-0.67)$. Rabbits with higher muscles percentages would be expected to have lower fat percentages $\left(r_{\mathrm{G}}=-0.64\right)$; bones percentages and muscles to bones ratio being essentially unchangeable ( $\mathrm{r}_{\mathrm{G}}=0.08$ and 0.04 , respectively).

\section{Genetic association between live body and carcass traits.}

Selection for daily gain and marketing body weight would result in rabbits with carcasses of higher percentages of boneless side and fat, and muscles to bones ratio $\left(r_{G}=0.64\right.$ to 0.85$)$ and lower percentages of fatless side and bones $\left(r_{G}=-0.38\right.$ to $0.74)$. At marketing, rabbits with higher girth at abdomen would be expected to yield lower percentages of fatless side, muscles, bones and fat $\left(\mathrm{r}_{\mathrm{G}}=-0.25\right.$ to -0.70$)$ and higher muscles to bones ratio $\left(\mathrm{r}_{\mathrm{G}}=0.63\right)$. Rabbits with longer bodies would give carcasses characterized by lower fatless side percentage and lower percentages of muscles and bones $\left(\mathrm{r}_{\mathrm{G}}=-0.19,-0.53,-0.11\right.$, respectively). In this data, correlations calculated for ear length were negative with percentages of boneless side and fat and muscles to bones ratio $\left(\mathrm{r}_{\mathrm{G}}=-0.27,-0.94\right.$ and -0.51 , respectively) and positive with percentages of muscles and bones $\left(\mathrm{r}_{\mathrm{G}}=0.88\right.$ and 0.66 , respectively). 
Egyptian J. Anim. Prod. (2008) 


\section{Indexes}

The full sib estimates of genetic and phenotypic (co) variances and the relative economic values obtained in the present study were used to construct ten selection indexes. The weighing factors, standard deviation, accuracy of selection for each index together with the relative efficiency in relation to the full index are given in Table 3. Within body weight traits, the comparison, in terms of accuracy of selection, among $I_{5}$ (including daily gain alone), $I_{4}$ (including marketing body weight alone), $I_{3}$ (including daily gain and marketing body weight) and $I_{2}$ (including the three traits) indicated their comparable contribution as a sources of information $\left(\mathrm{r}_{\mathrm{TI}}=0.90,0.87\right.$, $0.91,0.92$, respectively). Selection based on body linear measurements alone is expected to be $90 \%$ as efficient as the full index in improving aggregate genotype.

\section{Expected genetic gain}

Table 4 gives the expected genetic changes in each individual trait through use of the highest accurate indexes, $I_{2}, I_{3}, I_{4}, I_{5}$ and $I_{10}$. Selection based on these five indexes is expected to develop rabbits having better body weight at marketing $(+120 \mathrm{~g}$ to +153 $\mathrm{g})$, lower body weight at weaning ( -1 to $-19 \mathrm{gm})$ and limited daily gain $(+2.0$ to +2.3 $\mathrm{gm} /$ day). Higher content of fat ( +0.5 to +0.7 unit), lower content of muscles $(-0.36$ to -0.39 unit) and bones ( -0.2 to -0.4 unit) with higher muscles to bones ratio $(+0.2$ to +0.2 unit) are concomitantly expected.

It could be concluded that, whenever records for body weights are available, use of weaning weight (WW), marketing body weight (MW) and daily gain (DG) in the index:

$$
I_{2}=-0.82 \mathrm{WW}+36.9 \mathrm{DG}+0.92 \mathrm{MW} ;\left(\mathrm{r}_{\mathrm{TI}}=0.92\right)
$$

would be recommended to optimize selection for the given aggregate genotype. On the other hand if body linear measurements at marketing are the only available sources of information, the index:

$I_{10}=+85.0$ abdominal girth $\mathbf{- 7 2 . 1}$ ear length $\mathbf{- 1 7 . 5}$ body length; $\left(r_{\mathrm{TI}}=0.85\right)$ would be recommended. With both indexes, some increase in fat percentage should be tolerated.

\section{ACKNOWLEDGEMENTS}

I am greatly indebted to Mr. Alaa M. Eid, for providing me the rabbits at his Sanafer Rabbit farm.

\section{REFERENCES}

Blasco, A., J. Ouhayoun, and G. Masoero, 1992. Study of rabbit meat and carcass criteria and terminology. Journal of Applied Rabbit Research, 15:775-786.

Blasco, A., M. Piles, E. Rodriguez, M. Pla, 1996. The effect of selection for growth rate on the live weight growth curve in rabbits. 6th World Rabbit Congress, Toulouse, 1996. 2: 245-248.

Cunningham, E.P., R.A. Moen, and T. Gjedrem, 1970. Restriction of selction indexes. Biometrics, 23: 67-74.

Estany, J., J. Comacho, M. Baselga, and A. Blasco, 1992. Selection response of growth rate in rabbits for meat production. Genetique, Selection et Evolution, 24: 527-537. 
Harvey, W.R. 1990. User's guide for LSMLMW and MIXMDL, Least Squares and Maximum Likelihood Computer Program. The Ohio State University, Columbus (Mimeograph).

Lukefahr, S.D., H.B. Odi, and J.K.A. Atakora, 1996. Mass selection for 70-day body weight in rabbits. Journal of Animal Science, 74: 1481-1489.

Niedzwiadek, S. 1978. The evaluation of slaughter value and its application in the selection of rabbits. Krakow, Institute Zootechniki, Poland, 48 pp.

Polastre, R., A.S.A.M.T. Moura, and S.B. Pons, 1992. Expectations from a mass selection programme for growth rate in Selecta rabbits. Revista da Sociedade Brasileira de Zootecnia, 21:45-56. (In Portugese). Animal Breeding Abstracts, 1992, 60:7299.

Shemeis, A.R. and O.Y. Abdallah, 2000. Possibilities of developing favourable body fat partition via selection indexes - Application on rabbits. Archiv für Tierzucht, Dummerstorf, 43: 193-201. 
الإستجابة المرتبطة فى صفات الذبيحة عند استخدام أدلة انتخابية تتضمن وزن الجسم عند

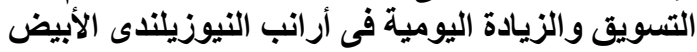

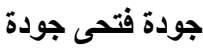

قسم الإنتاج الحيوانى، كلية الزراعة، جامعة عين شعس، شبرا، القاهرة، مصر

تم حساب تقدير ات المعالم الو راثية و المظهرية لصفات الجسم الحى و الذبيحة على 121 أرنب نيون نيوزيلندى

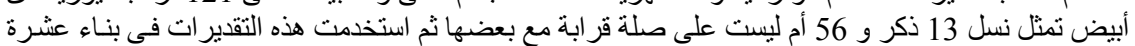

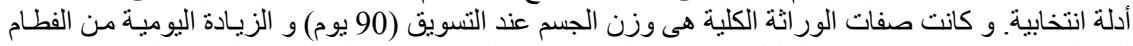

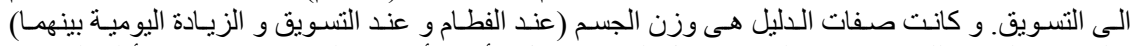

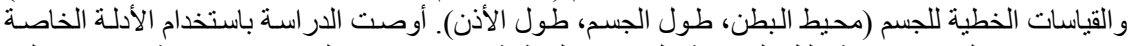

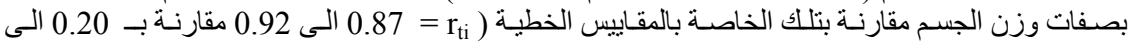

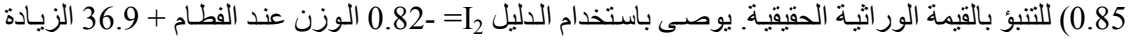
اليومية + 0.92 الوزن عند التسويق

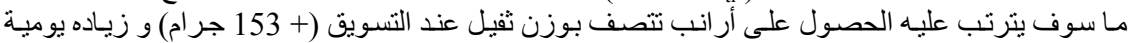

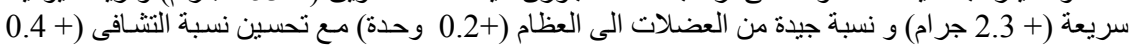

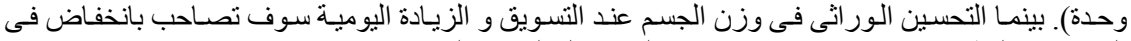

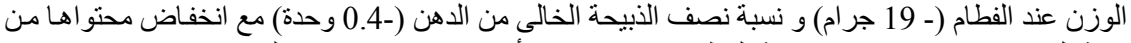

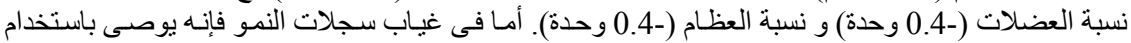
الدليل 
Table 2. Genetic (above diagonal) and phenotypic (below diagonal) between live body and carcass traits

\begin{tabular}{|c|c|c|c|c|c|c|c|c|c|c|c|c|}
\hline & \multicolumn{6}{|c|}{ Live body traits } & \multicolumn{6}{|c|}{ Carcass traits } \\
\hline & \multicolumn{3}{|c|}{ Body weights } & \multicolumn{3}{|c|}{$\begin{array}{l}\text { Body linear } \\
\text { measurements }\end{array}$} & & & & & & \\
\hline & $\mathrm{V}_{1}$ & $\mathrm{~V}_{2}$ & $\mathrm{~V}_{3}$ & $\mathrm{~V}_{4}$ & $\mathrm{~V}_{5}$ & $\mathrm{~V}_{6}$ & $\mathrm{~V}_{7}$ & $\mathrm{~V}_{8}$ & $\mathrm{~V}_{9}$ & $\mathrm{~V}_{10}$ & $\mathrm{~V}_{11}$ & $\mathrm{~V}_{12}$ \\
\hline \multicolumn{13}{|l|}{$\begin{array}{l}\text { i. Live body traits } \\
\text { a. Body weights }\end{array}$} \\
\hline $\mathrm{V}_{1}$ Weaning weight & - & -0.12 & -0.03 & -0.18 & 0.01 & -0.18 & 0.29 & 0.41 & 0.27 & 0.13 & -0.24 & -0.07 \\
\hline $\mathrm{V}_{2}$ Marketing body weight & 0.07 & - & 0.92 & 0.90 & 0.36 & -0.76 & -0.38 & 0.79 & 0.21 & -0.74 & 0.83 & 0.68 \\
\hline $\begin{array}{l}\mathrm{V}_{3} \text { Daily gain } \\
\text { b. Body linear } \\
\text { measurements }\end{array}$ & -0.19 & 0.92 & - & 0.89 & 0.37 & -0.72 & -0.40 & 0.64 & -0.67 & -0.73 & 0.85 & 0.65 \\
\hline $\mathrm{V}_{4}$ Abdominal circumference & -0.01 & 0.85 & 0.84 & - & 0.46 & -0.77 & -0.25 & 0.20 & -0.60 & -0.70 & 0.79 & 0.63 \\
\hline$V_{5}$ Body length & 0.06 & 0.35 & 0.35 & 0.31 & - & 0.05 & -0.19 & 0.32 & -0.53 & 0.11 & 0.38 & 0.15 \\
\hline $\begin{array}{l}\mathrm{V}_{6} \text { Ear length } \\
\text { ii. Carcass traits }\end{array}$ & 0.09 & 0.25 & -0.30 & -0.26 & -0.04 & - & 0.43 & -0.27 & 0.88 & 0.66 & -0.94 & -0.51 \\
\hline $\mathrm{V}_{7}$ Fatless side & 0.21 & -0.27 & -0.33 & -0.30 & -0.04 & 0.26 & - & -0.51 & 0.90 & 0.36 & -0.57 & -0.24 \\
\hline $\mathrm{V}_{8}$ Boneless side & 0.89 & 0.73 & 0.71 & 0.62 & 0.29 & -0.09 & -0.42 & - & 0.14 & -0.87 & 0.50 & 0.83 \\
\hline $\mathrm{V}_{9}$ Side muscles & 0.19 & -0.40 & -0.46 & -0.44 & -0.07 & 0.45 & 0.93 & -0.06 & - & 0.08 & -0.64 & 0.04 \\
\hline $\mathrm{V}_{10}$ Side bones & -0.03 & -0.71 & -0.69 & -0.62 & 0.25 & 0.22 & 0.42 & -0.95 & -0.05 & - & -0.67 & -0.99 \\
\hline $\mathrm{V}_{11}$ Side fat & -0.12 & 0.75 & 0.77 & 0.71 & 0.21 & -0.50 & -0.45 & 0.64 & -0.66 & -0.62 & - & 0.60 \\
\hline $\mathrm{V}_{12}$ Side muscle:bone & 0.09 & 0.65 & 0.61 & 0.55 & 0.27 & -0.13 & -0.08 & 0.93 & 0.20 & -0.98 & 0.51 & - \\
\hline
\end{tabular}


Table 3. Weighing factors for selection traits and index standard deviation $\left(\sigma_{\mathrm{I}}\right)$, accuracy of selection $\left(r_{\mathrm{TI}}\right)$ and relative efficiency (RE) for selection indices

\begin{tabular}{|c|c|c|c|c|c|c|c|c|c|c|}
\hline \multirow[b]{2}{*}{ Selection strategies } & \multirow[b]{2}{*}{ Index } & \multicolumn{3}{|c|}{ Weighing factors body weights } & \multicolumn{3}{|c|}{$\begin{array}{l}\text { Weighing factors body linear } \\
\text { measurements }\end{array}$} & \multirow[b]{2}{*}{$\sigma_{I}$} & \multirow[b]{2}{*}{$\mathrm{r}_{\mathrm{TI}}$} & \multirow[b]{2}{*}{$\mathrm{RE}^{*}$} \\
\hline & & $\begin{array}{c}\text { Weaning } \\
\text { weight } \\
\text { (WW) }\end{array}$ & $\begin{array}{c}\text { Marketing } \\
\text { weight } \\
\text { (MW) }\end{array}$ & $\begin{array}{l}\text { Daily } \\
\text { gain } \\
\text { (DG) }\end{array}$ & $\begin{array}{l}\text { Abdominal } \\
\text { girth } \\
\text { (AC) }\end{array}$ & $\begin{array}{r}\text { Body } \\
\text { length } \\
(\mathrm{BL})\end{array}$ & $\begin{array}{c}\text { Ear } \\
\text { length } \\
\text { (EL) }\end{array}$ & & & \\
\hline \multicolumn{11}{|c|}{ i. Based on all live body traits } \\
\hline Full index & $I_{1}$ & -0.70 & 1.03 & 37.34 & -12.8 & -18.7 & -104.2 & 0.029 & 0.94 & 100 \\
\hline \multicolumn{11}{|c|}{ ii. Based on body weights only } \\
\hline WW, DG, MW & $I_{2}$ & -0.82 & 0.92 & 36.9 & - & - & - & 0.028 & 0.92 & 97.9 \\
\hline DG, MW & $I_{3}$ & - & 0.49 & 69.0 & - & - & - & 0.027 & 0.91 & 96.8 \\
\hline MW & $I_{4}$ & - & 1.39 & - & - & - & - & 0.026 & 0.87 & 92.6 \\
\hline DG & $I_{5}$ & - & - & 100.6 & - & - & - & 0.027 & 0.90 & 95.7 \\
\hline \multicolumn{11}{|c|}{$\begin{array}{l}\text { iii. Based on body linear } \\
\text { measurements only }\end{array}$} \\
\hline $\mathrm{AC}$ & $I_{6}$ & - & - & - & 182.8 & - & - & 0.023 & 0.76 & 80.8 \\
\hline BL & $I_{7}$ & - & - & - & - & 219.7 & - & 0.013 & 0.20 & 21.3 \\
\hline EL & $I_{8}$ & - & - & - & - & - & -226.6 & 0.014 & 0.46 & 48.9 \\
\hline BL, EL & $I_{9}$ & - & - & - & - & 48.4 & -231.5 & 0.015 & 0.51 & 54.2 \\
\hline $\mathrm{AC}, \mathrm{BL}, \mathrm{EL}$ & $I_{10}$ & - & - & - & 85.0 & -72.1 & -17.5 & 0.026 & 0.85 & 90.4 \\
\hline
\end{tabular}


Table 4. Genetic changes expected with use of selection indexes (intensity of selection =1)

\begin{tabular}{|c|c|c|c|c|c|c|c|c|c|c|}
\hline & \multicolumn{10}{|c|}{ Indexes based on } \\
\hline & \multirow{2}{*}{$\begin{array}{c}\text { all } \\
\text { traits } \\
\\
\text { full } \\
\text { index } \\
I_{1} \\
\end{array}$} & \multicolumn{4}{|c|}{ body weights } & \multicolumn{5}{|c|}{ body linear measurements } \\
\hline & & $\begin{array}{l}\text { WW, } \\
\mathrm{MW}, \mathrm{DG} \\
I_{2}\end{array}$ & $\begin{array}{c}\mathrm{MW}, \mathrm{DG} \\
I_{3}\end{array}$ & $\begin{array}{c}\mathrm{MW} \\
\mathrm{I}_{4}\end{array}$ & $\begin{array}{c}\mathrm{DG} \\
I_{5}\end{array}$ & $\begin{array}{c}\mathrm{AC} \\
I_{6}\end{array}$ & $\begin{array}{c}\mathrm{BL} \\
I_{7}\end{array}$ & $\begin{array}{c}\mathrm{EL} \\
I_{8}\end{array}$ & $\begin{array}{l}\text { EL, } \\
\text { BL } I_{9}\end{array}$ & $\begin{array}{c}\mathrm{AC}, \mathrm{EL}, \\
\mathrm{BL} \\
I_{10}\end{array}$ \\
\hline \multicolumn{11}{|l|}{$\begin{array}{l}\text { i. Live body traits } \\
\text { a- Body weights, } g\end{array}$} \\
\hline Weaning weight (WW) & -15 & -19 & -14 & -6 & -19 & -8 & 0.7 & 6 & 5 & -1 \\
\hline $\begin{array}{l}\text { Marketing body weight } \\
\text { (MW) }\end{array}$ & 159 & 153 & 151 & 153 & 146 & 130 & 74 & 79 & 88 & 120 \\
\hline $\begin{array}{l}\text { Daily gain (DG, gm/day) } \\
\text { b- Body linear } \\
\text { measurements, } \mathbf{c m}\end{array}$ & 2.3 & 2.3 & 2.2 & 2.0 & 2.3 & 1.8 & 1.1 & 1.1 & 1.2 & 2.0 \\
\hline $\begin{array}{l}\text { Abdominal circumference } \\
\text { (AC) }\end{array}$ & 0.9 & 0.9 & 0.9 & 0.8 & 0.9 & 0.9 & 0.6 & 0.5 & 0.6 & 0.8 \\
\hline Body length (BL) & 0.2 & 0.2 & 0.2 & 0.2 & 0.2 & 0.3 & 0.9 & 0.02 & 0.2 & 0.25 \\
\hline Ear length (EL) & -0.3 & -0.2 & -0.3 & -0.2 & -0.2 & 0.2 & $\overline{-}-$ & -0.2 & -0.2 & -0.23 \\
\hline \multicolumn{11}{|l|}{ ii. Carcass traits } \\
\hline Fatless side $(\%)$ & -0.4 & -0.4 & -0.4 & -0.4 & -0.5 & - & $\overline{0.05}$ & -0.3 & 0.1 & -0.3 \\
\hline Boneless side (\%) & 0.6 & 0.4 & 0.5 & 0.6 & 0.6 & 0.6 & 0.3 & 0.3 & 0.3 & 0.4 \\
\hline Side muscles $(\%)$ & -0.4 & -0.4 & -0.4 & -0.3 & -0.4 & - & - & -0.3 & -0.4 & -0.4 \\
\hline Side bones $(\%)$ & -0.4 & -0.4 & -0.4 & -0.4 & -0.4 & $\begin{array}{c}- \\
0.3\end{array}$ & -0.1 & -0.2 & -0.2 & -0.2 \\
\hline Side fat $(\%)$ & 0.7 & 0.7 & 0.6 & 0.6 & 0.6 & 0.5 & 0.4 & 0.5 & 0.5 & 0.5 \\
\hline Side muscle:bone & 0.2 & 0.2 & 0.2 & 0.2 & 0.2 & 0.2 & 0.1 & 0.1 & 0.1 & 0.2 \\
\hline
\end{tabular}

